\title{
The Challenges in Effective Implementation of the Legislation to Protect the Domestic Economy by the Synchronization of International Agreements and Political Will. The Case of Kosova in Relation to CEFTA
}

\author{
Armand Krasniqi \\ University of Prishtina "Hasan Prishtina"
}

\author{
Doi:10.5901/ajis.2015.v4n2p499
}

\begin{abstract}
Eastern European countries seems that with difficulties are administrating the transition social and economic transition process even after more than one decade of conflicts and severe wars. The reasons of this process not only are numerous but their continued presence has not stopped. The identification, studding and the prevention is crucial to exit from this situation. One of the problems requiring an urgent solution is the implementation of the legislation to protect the domestic economy without violating the principles of market economy and policy synchronization with bilateral and multilateral agreements in this sphere. All countries now have created a modern legislative framework adequate and modern with the relevant institutions to implement the protection measures of the domestic economy. However, the implementation is almost impossible because of the lack of will and political decisions. Political perceptions, which are rooted in the problematic past from the laying of the former SFRY, some countries hesitate to implement the full international agreements and for this reason the eventual implementation of protective measures for the domestic trade automatically takes connotation of political rivalry. Concrete case to argue our claim is CEFTA agreement. Although CEFTA is designed to integrate in the economic plan the Balkans, for Kosovo came out as an inappropriate and harmful document. This is because especially Serbia and Bosnia and Herzegovina abstained from its application after declaration of independence of Kosova. This has caused damages to the domestic economy and every day more is thought to get out of this agreement. This situation carries with it numerous risks and irreparable damages.
\end{abstract}

Keywords: legislation, trade, antidumping, CEFTA, agreement.

\section{Introduction}

For more than a decade, Kosovo has had a very high negative balance of trade. Continuously the exports have been low, while imports have been very large. With the aim to affirm the principles of market economy and economic development with modern liberal basis, in scientific and academic field, are treated issues like reducing the tariff and non tariff barriers in the area of international business relation. This proactive approach is not of the same dynamic and dimension in cases when is to be justified the implementation of protective mechanisms for domestic economy. Kosova as one of the smallest countries as for the size as well for its economic impact in the region very often is damaged precisely by effects of the implementation of these economic policies. With all the problems and difficulties the country is facing in this process it must be mentioned the negative effects of global crisis that directly has affected the economy. Overall and after the end of the war in 1999, governance of UNMIK and declaration of the independence of the Republic of Kosova we can argue that the political conflicts not only are not diminished but they also have a dominant effect on international agreements. In fact, has been created the perception that one the factors for this grave economical situation in Kosova is the lack of the legislation, respectively non-implementation of the same. Let's consider that this thesis does not stand. In our country, at least so far, exist the legislation that with commodity regulates all the economic life areas but the essential of the problems lies in the lack of a program respectively an economic analyzed strategy, designed and elaborated according to the concept called by Drucker as SMART. The lack of such approach, the lack of such documents and priorities to determine which will be the branch or branches of the economy that must be considered supportive for local economic development, not only brings a difficult economic position but there is no possibility to implement the legislation. The State and the modern right have the function to regulate the economic life by creating conditions and circumstances to implement the economic policies for liberalization and integration. The duty of governmental institutions is not only the integration process and the liberalization with no measurable criteria of the economy but in parallel also the obligation to undertake the effective and efficient measures to protect the economy by using mechanisms and permitted standards to 
save the national economic identity toward the storms and effects of the globalization. The data from the Foreign Trade in Kosova show a higher trade deficit for January 2015 of $€ 110.8$ million compared to the same period of 2014 with $€ 109.4$ million. CEFTA is created to eliminate the obstacles for the reciprocal trade between Member States, to create favourable conditions to develop the business, to encourage trade and economic cooperation, to intensify the economic relations for mutual benefits and to contribute in the integration process in EU, to contribute in the development of trade relations with EU and for the integration of multilateral trade system. But now the question arises if this agreement's conditions are fulfilled or not? All the data give a negative result. Based on these data another question arises: should we react to improve the situation? Of course yes. The only model to be composed is the reconsideration of feasibility study of the national economy, creation of development policies based to the analyse of the FS and at the end the review, the completion and drafting a legislative framework to implement these policies. Meanwhile, in the political cooperation aspect a mechanism must be found that in maximum will eliminate the politic interferences. Therefore this process must be considered as a process of measures synchronization to develop and protect the domestic economy.

\section{Legislative Framework to Protect the Domestic Economy}

Kosovo is still in the process to elaborate its internal legislation for foreign trade in way to adapt this legislation with that of the European Union. In 2011 a new law has been designed for the Foreign Trade. This act is evaluated to be crucial and determine the principles that regulate the relations of the foreign trade of Kosovo. In the last two or three years Kosovo has completed the legal framework for the compensation measures/ reserve measures in trade. However, the Law for Antidumping Measures and Countervailing measures are not yet completely in line with international best practices. Below we will present a summary of the relevant local legislative framework for the trade area.

The Juridical act with a basic importance to regulate the local economy in relation with the international elements is the law for the foreign trade Nr. 04/L-048. The Law for Foreign trade is a general term that determines the rules for the transactions of imports and exports, the import and the export of the technology and the international trade in goods and services. This act determines the conditions to manage and control the foreign trade in the country, as well as determines the general rules to carry out the foreign trade between persons inside or outside the territory of Kosova in compliance with the best international practices.

According to the dispositions, the request or the authorisation to establish protection measures is regulated in that way that will not be in contradiction with the Article 4 of this law. If a provision of the present law specifically requires or authorizes the imposition of a restrictive measure the Government shall or may, as appropriate, issue a normative act establishing such restrictive measure; provided, however, that each such restrictive measure so established must comply with all of the following criteria: It must be clearly authorized by and consistent with the concerned provision of the present law; It must be clearly related to and clearly necessary for the achievement of the purpose specified in such provision; Its type and scope must be limited to the minimum necessary to achieve such purpose; Its implementation shall be done in the manner that creates the least possible interference with and imposes the least possible burden on external trade activity and the general freedom of economic activity; It shall not be contrary to any international agreement that is binding on Kosovo (Law on Foreign Trade, Art.5). The law for foreign trade has a special and important position within the legislative framework that regulates the economy. Its formal-juridical importance is materialized based to the object and the aim of legal regulation of this matter.

In global trends the economic policies are oriented toward removing the customs tariffs and non-tariff barriers in support of increasing the economic integration, in trade and in competition field. As such these are very important means and instruments. With antidumping and countervailing measures is meant the legal possibility to put limitation in the international trade, replacing of existing limitation or the creation of additional barriers. By this Law are set out the rules on procedures for imposition of anti-dumping measures to the imports, which are dumping objects, and countervailing measures to the subsided imports, in order to protect the domestic Kosovo industry and interests of the Republic of Kosovo (Law on anti dumping and countervailing). This Law applies to the anti-dumping and countervailing measures, which is dumped or benefits from subsidies of the government or a public authority of the exporting country or the country of origin provided that the imports of the product cause or threaten to cause material injury to the domestic industry (Law on anti dumping and countervailing, Art. 2). Anti-dumping and/or countervailing measures shall be imposed only after respecting the relevant procedures and carrying out the investigations in accordance with the requirements specified in this Law (Anti dumping and countervailing Law, Art. 3)

Customs and Excise Code of Kosova is one of the most important acts within the legislative framework for the trade and costumes administration. As such is an important mechanism to collect the revenues (fiscal administration), 
facilitation the commerce and attraction of the investments in the country. The Code is in compliance with the Customs Code of the European Union of 1992. This is very important, because the rapprochement with the EU is a priority of Kosova and this requires facilitating and harmonising the internal laws of Kosova with the legislation of EU. There are plans to change and amend laws in way to be in compliance with the plan of EU for the custom ('EU Customs Blueprint' of 2008, or with the new versions of EU plan for Customs (See: file: ///C:/Users/user/Downloads/5._eu_customs_ blueprints.pdf).

Law No.04/L-047 on Safeguard Measures on Imports sets out the principles and procedures relating to application of safeguard measures in cases when a product is imported in Kosovo in such increased quantities that cause injury or threat of serious injury to domestic producers of like or identical goods. This is considered to be in full compliance with the WTO agreements and directives, respectively EU and CEFTA provisions, except the deadline for law implementation. The agreement of WTO for safeguard measures determines that the measures should be initially implemented in four years, and if the review determines that the domestic industry damages by the by rapid growth of imports is still on going, than can be continued for other four years. The Law on Safeguard Measures in imports determines a deadline of eight years for the implementation of the safeguard measures. This is in contradiction with provisions of CEFTA which are even more restrictive. Its signatory States agreed to implement protective measures for one year, and if the damage continues, then for an additional year. The legislation for quality infrastructure the Progress Reports of EU for 2009 and 2010 recognize that Kosova progressed in achieving the European standards for the quality infrastructure and are relevant for trade area, thus those of the accreditation, standardization and metrology. The progress achieved deals with approved legislation in these three fields. The activity of mechanisms for the quality infrastructure in Kosovo is based in these laws: Law for Standardization Nr. 2009/03/L. Law for Metrology nr. 2010/03-L-203. Law for Precious Metals Products nr.2004/28. And the Law for Accreditation nr. 2005/02 - L 43 nr. 2011/04 - L - 007. The department of Industry is another important part of the infrastructure of the quality in Kosovo. (see the discussion below), especially the office for quality infrastructure. The last one is responsible to issue technical rules. The activities are based to the law for the General Security of the Products nr. 04/L-078 and the law for Technical Requirements for Products and the Evaluation of Conformity nr. 04/L-039.

\section{Negative Effects and Trade Deficit with CEFTA}

Kosova is part of CEFTA since 2007 (UNMIK signed the agreement with CEFTA-S on behalf of Kosova on 19 Decembre 2006. On 26 July 2007 Kosova became a full member of CEFTA). The agreement of CEFTA in that time has been signed by UNMIK, in the quality of the only authority that had the right to represent Kosova in relation with foreign countries. Fourteen months after signing the agreement with CEFTA, Kosova declared its independence. After the declaration of independence, the institutions failed to articulate a clear attitude regarding the representation of Kosova in international agreements. Seven years after the membership of Kosova in CEFTA and after five years of independence declaration, the kosovar opinion and the businesses representatives are divided in those who think that Kosova must stay in CEFTA and those who think that Kosova should leave CEFTA (GAP Institute).

Realistically CEFTA is one of the first multilateral agreements of regional kind that Kosova has inherited from UNMIK and as such is challenging for the institutions of Kosova. Without any doubt as a special regional agreement is considered an excellent possibility to open the doors toward the regional and European integration. But from the Kosovo entrance in contractual relation with other countries has damaged largely the local businesses. According to the evaluation of the professional institutions the membership in CEFTA is likely to be an unfair step. According to the results of this membership there are millions of looses, discouraged investors and many conflict situation (Gap Institute, 2014. The evaluation given much earlier recommended the institutions to take the necessary measures to put quotes for the imported products, the use of all the legal means within CEFTA to resolve the agreement with other countries in case there are not alternatives, Kosova should leave CEFTA and do a bilateral agreement with each country separately. The trade deficit in Kosova is still high and this deficit is increased after the entrance of Kosova in CEFTA.

\section{Measures to be Taken to Synchronize the Legislative Framework for Economic Policy}

The general socio - economic situation in Kosova is alarming. The unemployment in growth, the high scale of informal economy, the lack of foreign investments, the impossibility to protect the economy and domestic products are only some factors to be improved. For this reason, the creation of an appropriate institutional environment (including the institutions for trade or have to do with the trade) is an essential factor for the success or failure of policies that aim to increase the 
competition of domestic industry. The institutions dealing with trade must pay attention to the following issues. There is an urgent need for a vital development of institutional, human and technical capacities that deal with the trade. The gap should be closed through the better use of existing resources, by adding capabilities to existing resources, employing young people and through foreign aid and long-term.

The further progression in approximation of legislation have to deal with the trade is necessary. Also the administrative capacities, human resources must be used to accomplish the legal framework and to implement the existing dispositions. Coordination mechanisms in Kosovo trade system should be strengthened further. Probably in this area is still needed the outside help to make sustainable these processes. A new approach also is needed to enhance the international competitiveness of domestic industries. This approach should be based on an important premise: trade policy actions should relate to Kosovo's development priorities, such as poverty reduction, job creation, and improving welfare for citizens. The comprehensive new approach should be a mix of the following mechanisms: further liberalization of trade and caring to create market access for local producers. In addition, should make more effective the existing arrangements for trade liberalization, which is part of Kosovo (such as CEFTA). At the same time, Kosovo must complete legislation that is consistent with WTO principles regarding the reserve measures to target illegal activities or large flows of imports from CEFTA member states. The specific sectional policies to increase competitiveness of domestic industries and production companies should be considered. Kosovo's trade policies offered in 2010 in the form of recommendations regarding the development of the export base of the industrial sector and agriculture should be reviewed on the basis of new circumstances. These proposals must be fit and should be included in use through regulation of instruments and enforcement mechanisms. In addition, sectional policies require a coordinated approach for many commercial policies, particularly tariff policy. Any change in the tariff structure should be taken with caution, since they influence the behaviour of consumers and producers, as well as affect government revenue. Changes in the level of fees should be aimed at maintaining the average tariff rate across the entire spectrum, in order to avoid endangering government revenues. Finally, the new approach should rely on incomes from FDI, an important source of competition, transfers of knowledge and indirect impact. Trade policy goes through a particular cycle policy, which means their review and redrafting, then evaluating the instruments proposed (ex-ante evaluation). Further the evaluated policies, adjusted and ex-post reconsidered must be implemented. This process should happen constantly. In order for this process to function properly, a vital factor is the availability and quality of data for international trade. Data and statistics are essential for decisionmaking that is based on evidence. Any proposal made above, should be filtered through the lens of modelling and policy analysis. The analysis should provide answers to possible effects of trade policies can have on consumers, manufacturers and government revenue, as well as poverty reduction, job creation, economic growth and general welfare.

\section{Conclusions}

Kosovo implements a liberal market regime. Foreign trade has been liberalized since 2000 and follows the standards set by the European Union and the World Trade Organization. Although Kosovo is not yet a WTO member from 2000 applies the WTO regime on import licensing procedure. Although Kosovo has a complete legislative framework for regulating and protecting the local economy appears that they are ineffective and unenforceable due to a chronic trade deficit. Strategic recommendations to address these challenges identified have included and adjusted in several steps. The competent institutions calmly and without the influence of logic for a liberal economy, have to tackle the main challenges that were mentioned in the paper. By addressing this issue I conclude that the creation of a proper institutional environment dealing with trade is an essential factor for the success or failure of policies aimed to increase the competitiveness of local industries. Further progress of the legislative framework that deals with foreign trade is necessary. Administrative capacity and human expertise should be used to supplement the legal framework and to implement existing provisions. Coordination mechanisms in the system of protection of Kosovo's economy should be strengthened further. Apparently, in this area is still needed the foreign assistance to make sustainable these processes. This approach should be based on a premise of synchronism such as policy actions on the economy should be linked to national development priorities such as poverty reduction, job creation, and improving the welfare of citizens. Comprehensive new approach should be a composition mechanisms in the field of further liberalization of trade but with careful to create greater access to the market for domestic producers. Regarding relations with CEFTA, in certain cases, is recommended the imposition of provisional measures Tech Rebalancing Sebum Control. This would rebalance temporary losses incurred due to the unfavourable position of the country in this agreement. Also, it is recommended the application of quotas for certain products that is not contrary to the legislation. The government should establish quotas for the protection of some local 
products, which will provide and will make these products more competitive in the local market, versus imported. Local competent institutions should be more effective in the area of the existing arrangements for trade liberalization, which part is Kosova. At the same time, Kosovo must complete the legislative framework in conformity with WTO principles regarding the reserve measures. This increases the competitiveness of domestic industries and the production of Companies. Still there is a need for a comprehensive approach to trade policy process so that these go through a special process of policy. Initially through the development, the assessment of policy instruments that are proposed for the final implementation this should finally be synchronized to the effective legislative framework. Such a process should happen constantly

\section{References}

\section{Books}

Drukerit P., SMART concepts "Specific, Measurable, Achievable, Realistic, and Timely" available at:https://wwww.managers.org.uk/ media/Files/Campus\%20CMI/Checklists\%20PDP/Setting\%20SMART\%20objectives.ashx

\section{Laws}

Law on Foreign Trade 04/L-048/ Law published in Official Gazette of Republic of Kosovo, Nr28., 16 December 2011

Law nr.04/I-240 on Anti-dumping and Coundervailing measures. Law published in Official Gazette of Republic of Kosovo, Nr.35/5, June 2014.

Code Nr. 03/L-109 Customs and Excise Code of Kosova.

Law for Standardization, Nr. 2009/03/L

e Law for Metrology nr. 2010/03-L-203

Law for Precious Metals Products nr.2004/28

Law for Accreditation nr. 2005/02 - L 43 nr. 2011/04 - L - 007.

Law for the General Security of the Products nr. 04/L-078

Law for Technical Requirements for Products and the Evaluation of Conformity nr. 04/L-039.

\section{Website Resources}

https://www.rks-gov.net/sq-AL/Bizneset/EkonomiaJashtme/Pages/CEFTA.aspx

GAP Institution "Policy Analysis" March 2011, http://www.institutigap.org/documents/34333_KosovaCEFTA.pdf - acceded on 28.02 .015 Institute for Advanced Studies "Kosovo's participation in regional organizations and initiatives" Policy Paper Nr. 5/14 - October 2014; http://www.kipred.org/advCms/documents/81929_Pjesemarrja\%20e\%20Kosoves\%20ne\%20organizatat\%20dhe\%20iniciativat\%2 Orajonale.pdf - acceded on 01.03.2015. 
